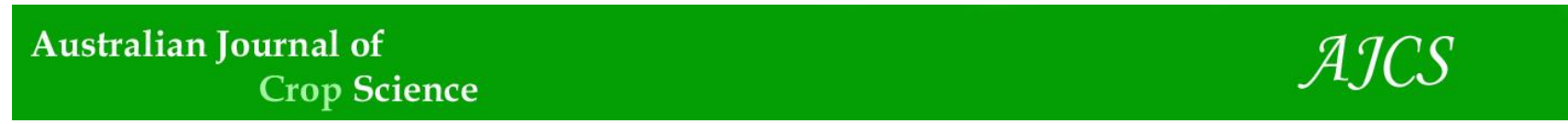

AJCS 14(09):1379-1384 (2020)

ISSN:1835-2707

doi: 10.21475/ajcs.20.14.09.p2249

\title{
Chemical characterization and determination of in vivo and in vitro antifungal activity of essential oils from four Eucalyptus species against the Hemileia vastatrix Berk and Br fungus, the agent of coffee leaf rust
}

\author{
Alex Rodrigues Silva Caetano ${ }^{1}$, Sara Maria Chalfoun ${ }^{3}$, Mario Lúcio Vilela Resende ${ }^{2}$, Caroline Lima \\ Angélico $^{3}$, Wilder Douglas Santiago', Maísa Lamounier Magalhães ${ }^{5}$, Danúbia Aparecida de Carvalho \\ Selvati Rezende', Luana Isac Soares', David Lee Nelson ${ }^{4}$, Maria das Graças Cardoso ${ }^{* 1}$ \\ ${ }^{1}$ Departamento de Química, Universidade Federal de Lavras (UFLA), CEP 37200-000, Lavras, Minas Gerais, Brazil \\ ${ }^{2}$ Departamento de Fitopatologia, Universidade Federal de Lavras (UFLA) CEP 37200-000, Lavras, Minas Gerais, Brazil \\ ${ }^{3}$ Empresa de Pesquisa Agropecuária de Minas Gerais, Campus Universitário, CEP 37200-000, Lavras, Minas Gerais, \\ Brazil \\ ${ }^{4}$ Programa de Pós-Graduação em Biocombustíveis, Universidade Federal do Vale do Jequitinhonha e Mucuri, CEP \\ 39100-000, Diamantina, Minas Gerais, Brazil \\ ${ }^{5}$ Departamento de Ciências dos Alimentos, Universidade Federal de Lavras (UFLA) CEP 37200-000, Lavras, Minas \\ Gerais, Brazil
}

*Corresponding author: mcardoso@ufla.br

Abstract

Essential oils, also known as volatile oils, are substances produced through the secondary metabolism of plants. In this study, we determined the chemical composition and the in vitro and in vivo antifungal activity of the essential oils from four species of Eucalyptus, Eucalyptus citriodora, Eucalyptus camaldulensis, Eucalyptus grandis and Eucalyptus microcorys, against the Hemileia vastatrix fungus. The essential oils from these four species of Eucalyptus were extracted from their leaves by the hydrodistillation technique using a modified Clevenger apparatus. The chemical characterization was performed by gas chromatography coupled with a mass spectrometer detector and by gas chromatography using a flame ionization detector. The antifungal activities of the essential oils against $H$. vastatrix were studied by evaluating the percentage of spore germination using the microdilution test for in vitro assays. The curative and preventive effects were evaluated in in vivo tests. The principal constituents of the essential oil from E. citriodora were citronellal, citronellol and isopulegol, while E. camaldulensis produced 1,8-cineole, $\alpha$-terpineol and $\alpha$-pinene. 1,8cineole, $\alpha$-pinene and $\alpha$-terpineol were obtained from $E$. grandis and 1,8-cineole, $\alpha$-pinene and trans-pinocarveol were the principal components in the essential oil of E. microcorys. In vitro and in vivo antifungal activities against the fungus under study were observed for most of the essential oils, except the essential oil from E. microcorys, for which no preventive antifungal activity was observed. Only the curing of infection by the $H$. vastatrix fungus was observed with this oil.

Keywords: Coffee; Coffee rust; Microbiological activity; Natural products; Organic agriculture.

Abbreviations: FID_flame ionization detector; GC_gas chromatography; MS_mass spectrometer.

Introduction

Agribusiness is the main economic activity in Brazil. Brazil is the leading producer of coffee beans, and its production is concentrated in the states of Minas Gerias, São Paulo, Espirito Santo, Rondônia, Bahia and Paraná (Brazil, 2017). The production of coffee beans has declined in Brazil since 1970s, when the Hemileia vastatrix B. fungus, known as coffee rust, began contaminating coffee plantations throughout the country. Since then, its control has increased the cost of the production of coffee beans, and when it is uncontrolled, the disease results in a significant reduction in the quality, productivity and longevity of the plants. At present, the rust is considered the principal cause of loss in the production of coffee beans. Fungicides are used to combat the microorganisms commonly found in the crop and after harvest, but they contain substances that can cause damage to the applicators and environment, as well as leaving dangerous residues in the final product (Zambolim, 2016).

In contrast to the harm caused by the use of chemicals, essential oils have been studied as a viable alternative for the substitution of these products because of their diverse biological properties. They are composed of substances of natural origin formed by the secondary metabolism of several plants species, giving rise to a complex mixture of several compounds that haveantifungal activity, among other activities (Rezende et al., 2017).

The essential oils from eucalyptus are mainly extracted from the leaves, and they are rich in in monoterpenes and sesquiterpenes. The yields of essential oils from Eucalyptus species varies according to the seasonal period. There is an 
increase in oil production in the summer and a decrease in production in the spring. There is a water deficit in the soil in the spring that compromises the production of essential oils (Silva et al., 2006). The method of extraction of essential oils directly influences the quantity and variety of chemical constituents in the oils of Eucalyptus species, the most commonly used methods being hydrodistillation and steam distillation (Fathi; Sefidkon, 2012).

These essential oils exhibit growth inhibition, fungicidal, bactericidal and allelopathic activities. The species most widely used in Brazil for extracting the essential oils are $E$. citriodora and $E$. globus because they contain high concentrations of citronellal and 1,8-cineol substances that are widely used in medicine and in the cosmetics industry (Salgado et al., 2003; Barbosa et al., 2016).

The essential oils of Eucalyptus spp. are being widely used as bioactive agents in various crops of commercial interest. The application of the essential oil results in the stimulus of plants to activate their defense mechanism, producing phytoalexins and activating pathogenesis proteins, in addition to exerting a direct toxic effect on microorganisms and pests (Pereira et al., 2012b; Steffen et al., 2010). The duration of the allelopathic effect can be a few days or weeks, or it can persist throughout the life cycle of the plant (Heil; Baldwin, 2002).

The objective of this work was to characterize the essential oils from four Eucalyptus species ( $E$. citriodora, $E$. camaldulensis, E. grandis and E. microcorys) and to evaluate the in vitro and in vivo antifungal activity of these oils against the $H$. vastatrix fungus.

\section{Results and Discussion}

\section{Chemical characterization of essential oils}

The compositions of the essential oils from the four species of Eucalyptus are presented in Table 1. The compositions of the essential oils of the Eucalyptus species were different for all the samples. Two compounds (1,8-cineole and $\alpha$ pinene) were common to the essential oils of $E$. camaldulensis, E. microcorys and E. grandis.

On the basis of the results obtained by the analysis of the chemical constituents by the PCA technique (Figure 1), the samples were separated into two chemical groups to highlight their similarities and differences with $96.48 \%$ confidence. Group I was composed of the essential oils from E. camaldulensis, E. grandis and E. microcorys, and Group II is composed of the essential oil from E. citriodora. The constituents responsible for significantly distinguishing between the groupings were (7) citronellal (Group I) and (1) 1,8-cineol, (2) $\alpha$-pinene and (10) $\alpha$-terpineol (Group II). The principal constituents in the essential oil of $E$. citriodora were citronellal, citronellol and iso isopulegol. Those from $E$. camaldulensis were 1,8-cineole, $\alpha$-terpineol and $\alpha$-pinene). The components of $E$. grandis were 1,8-cineole, $\alpha$-pinene and $\alpha$-terpineo and components of the essential oil from $E$. microcorys were 1,8-cineole, $\alpha$-pinene and transpinocarveol. Estanislau et al. (2001) identified 19 compounds in the essential oil of $E$. grandis. The principal compounds were $\beta$-pinene, o-cymene, $\gamma$-terpinene and $\alpha$ terpineol. The authors did not mention the presence of 1,8cineol, which was found in the present work (37.43\%).

Dogan et al. (2017) analyzed the composition of the essential oil from $E$. camaldulensis and found $p$-cymene, 1,8- cineol, $\alpha$-pinene and $\alpha$-terpinol as the main constituents, which is consistent with the results found in this work. Barbosa et al. (2016) reported that citronellal was the principal constituent in high concentrations in nine essential oils extracted from $E$. citriodora obtained from different locations in Brazil. Other compounds, such as citronellol and isopulegol were also found in low concentrations, which corroborates the data obtained in this work, where $88.83 \%$ oil from E. citriodora was citronella. Estanislau et al. (2001) identified seven constituents in the essential oil of $E$. microcorys, such as 1,8-cineole (86.72\%), $\alpha$-terpineol $(3.90 \%)$ and p-cymene $(2.82 \%)$. Their result corroborates those of this work.

The variation in the chemical composition of an essential oil of the same plant species is due to the fact that the essential oils are secondary metabolites produced by the plants as a form of defense and providing better conditions of development for the plant, thus, the environment influences its production. Edafoclimatic factors and attacks by insects and microorganisms can also influence the composition of essential oil of the same plant species (Goobo-Neto; Lopes, 2007).

\section{Determination of the in vitro antifungal activity}

The results of the determination of the in vitro antifungal activity of the essential oils from four Eucalyptus species against the $H$. vastatrix fungus are presented in Table 2 . In vitro antifungal activity against the $H$. vastatrix fungus was observed for all the essential oils listed in Table 2. A dosedependent relationship was observed, by which the antifungal activity was increased with increasing concentrations of the oils. Antifungal activity was observed for all the essential oils at concentrations much lower than that observed with the control fungicide (Opera), which was tested at a concentration of $3000 \mu \mathrm{L} . \mathrm{L}^{-1}$.

The highest antifungal activities at the lowest concentrations were observed for the essential oils of $E$. camaldulensis, $E$. citriodora and E. microcorys. They inhibited the germination of $H$. vastatrix spores by $100 \%$ at a concentration of $50 \mu \mathrm{L} \mathrm{L}$ 1 , whereas $100 \%$ inhibition was obtained with the essential oil from E. grandis at the concentration of $1000 \mu \mathrm{L} . \mathrm{L}^{-1}$. A high antifungal activity was noted for the essential oil from E. citriodora, which contained citronellal (88.83\%) as principal chemical constituent, thereby demonstrating the possibility of its application for the purpose tested.

The treatment with the essential oil of $E$. grandis changed the physical profile of the spores, passing from a spherical geometric form and orange color (negative control) to a wilted (untwisted) form. Rasooli et al. (2006) cite the fact that the compounds present in the essential oils caused morphological alterations in the hyphae, vacuolization and disorganization of the cytoplasm, rupture of the plasma and the mitochondrial membranes, among other organelles, when they are in direct contact with the microorganisms.

This change in the physical and visual appearance of the microorganism under study might have occurred because of the interaction of the components of the essential oil from E. grandis with the fungus membrane, which consists of ergosterol. This interaction increases the permeability of the membrane and causes leakage of cellular materials and ions (Kedia et al., 2015). 
Table 1. Compositions of the essential oils from the four species of Eucalyptus.

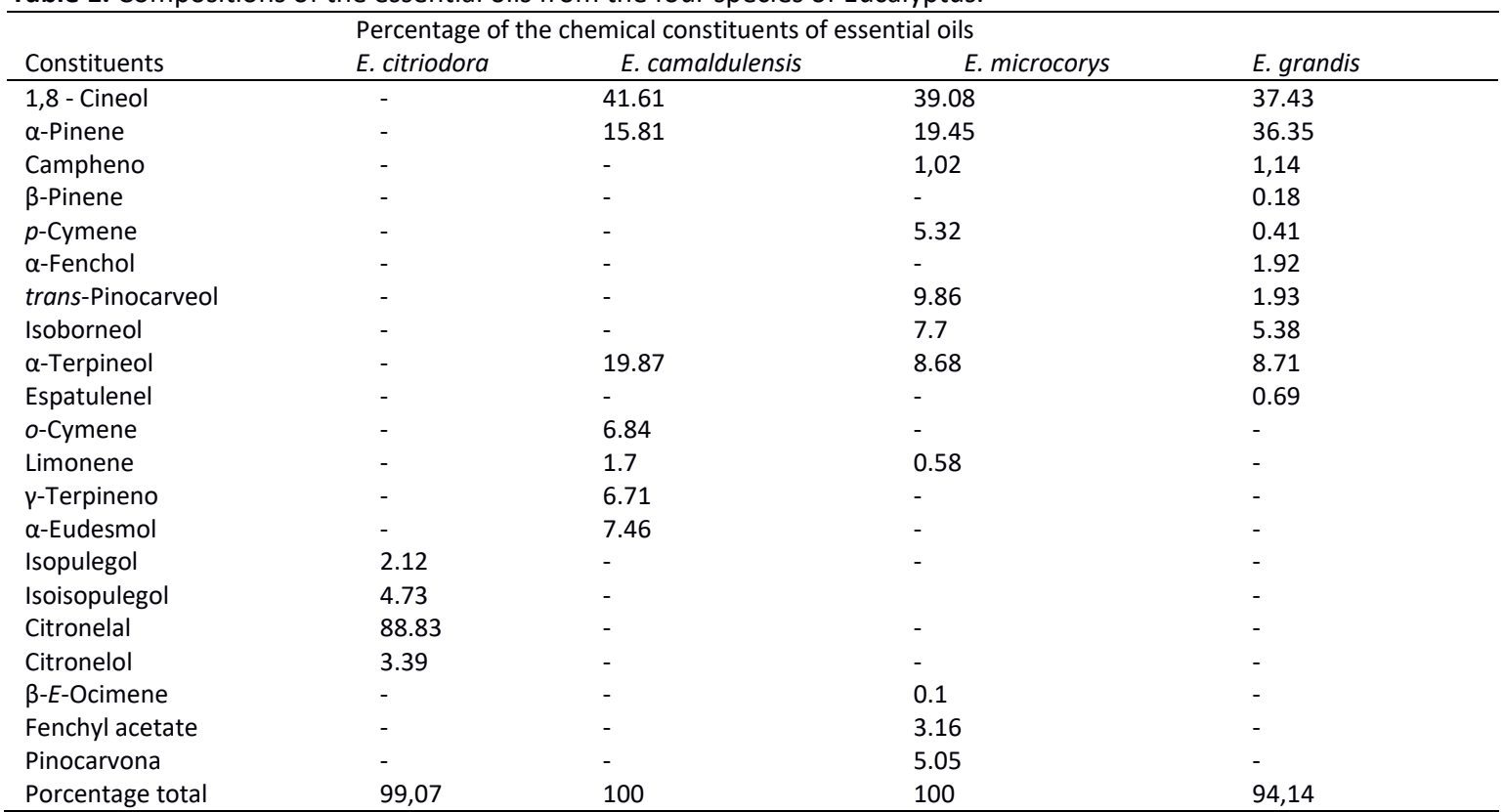

*The amount of each chemical constituent of the essential oils is expressed as a percentage. (-): unidentified chemical component.

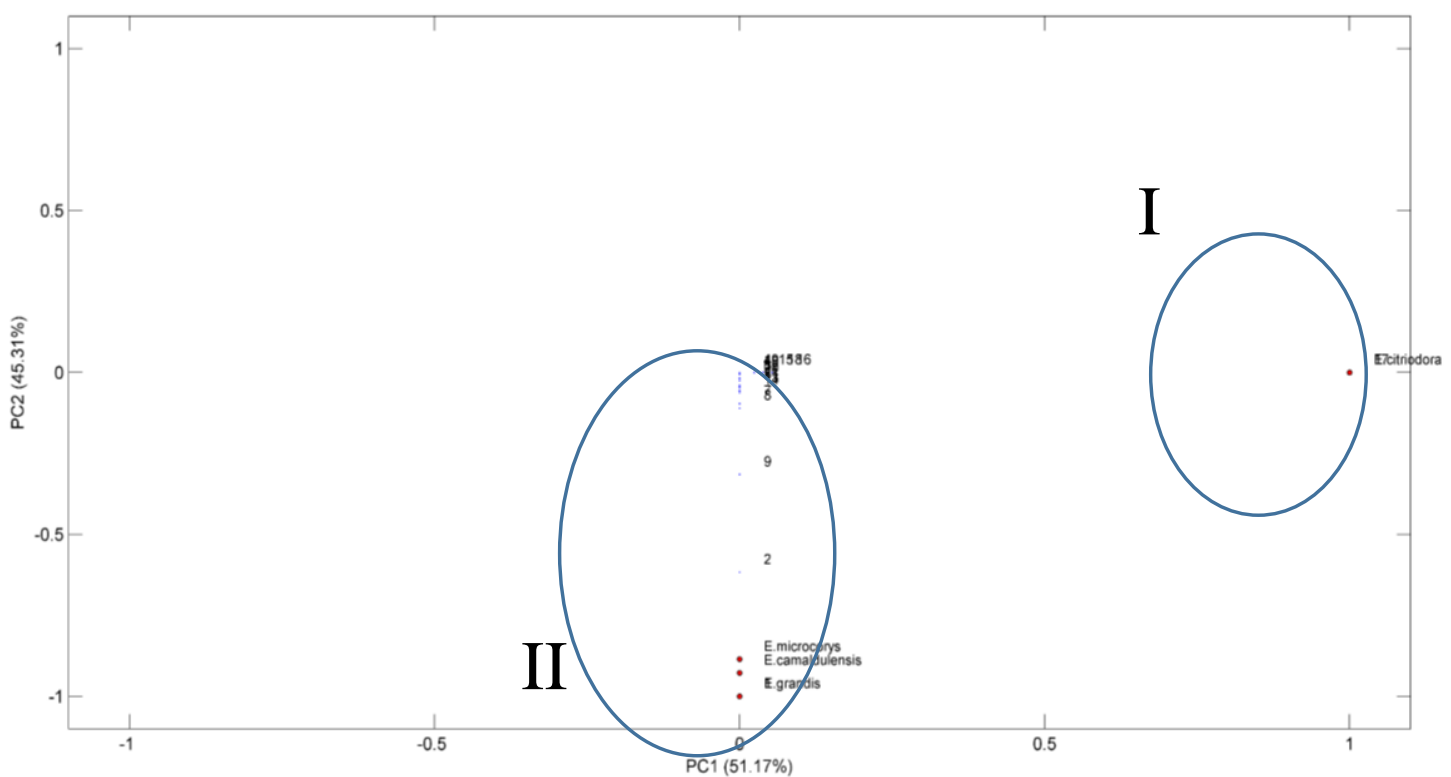

Fig 1. Bi-dimensional x PC2 graph of the componentes of the essential oils from four species of Eucalyptus. *(7) citronelal, (1) 1,8-cineol, (2) $\alpha$ pineno e (10) $\alpha$-terpineol.. * (7) citronelal, (1) 1,8-cineol, (2) $\alpha$-pineno and (10) $\alpha$-terpineol.

Table 2. In vitro antifungal activity of the essential oils from five Eucalyptus species against $H$. vastatrix.

\begin{tabular}{|c|c|c|c|c|}
\hline \multirow{2}{*}{$\begin{array}{l}\text { Concentration } \\
\text { Essential oil } \mu \mathrm{LL}^{-1}\end{array}$} & \multicolumn{4}{|c|}{ Percentage inhibition of germination of $H$. vastatrix spores } \\
\hline & E. grandis & E. citriodora & E. microcorys & E. camaldulensis \\
\hline $\mathrm{CN}$ & $12.36 \mathrm{eA}$ & $8.75 \mathrm{cA}$ & $10.01 \mathrm{cA}$ & $3.96 \mathrm{cB}$ \\
\hline 25 & $57.70 \mathrm{~dB}$ & $76.05 \mathrm{bA}$ & $79.19 \mathrm{bA}$ & $77.27 \mathrm{bA}$ \\
\hline 50 & $89.91 \mathrm{cB}$ & $95.09 \mathrm{aA}$ & $97.65 \mathrm{aA}$ & $97.23 \mathrm{aA}$ \\
\hline 100 & $92.85 \mathrm{bB}$ & $98.80 \mathrm{aA}$ & $98.84 \mathrm{aA}$ & $97.99 \mathrm{aA}$ \\
\hline 250 & $95.04 \mathrm{bB}$ & $100.0 \mathrm{aA}$ & $100.0 \mathrm{aA}$ & $98.10 \mathrm{aA}$ \\
\hline 500 & $95.22 \mathrm{bB}$ & $100.0 \mathrm{aA}$ & $100.0 \mathrm{aA}$ & $100.0 \mathrm{aA}$ \\
\hline 1000 & $98.61 \mathrm{aA}$ & $100.0 \mathrm{aA}$ & $100.0 \mathrm{aA}$ & $100.0 \mathrm{aA}$ \\
\hline 1500 & $100.0 \mathrm{aA}$ & $100.0 \mathrm{aA}$ & $100.0 \mathrm{aA}$ & $100.0 \mathrm{aA}$ \\
\hline 2000 & $100.0 \mathrm{aA}$ & $100.0 \mathrm{aA}$ & $100.0 \mathrm{aA}$ & $100.0 \mathrm{aA}$ \\
\hline 3000 & $100.0 \mathrm{aA}$ & $100.0 \mathrm{aA}$ & $100.0 \mathrm{aA}$ & $100.0 \mathrm{aA}$ \\
\hline $\mathrm{CP}$ & $100.0 \mathrm{aA}$ & $100.0 \mathrm{aA}$ & $100.0 \mathrm{aA}$ & $100.0 \mathrm{aA}$ \\
\hline
\end{tabular}

*The means followed by the same lowercase letter in the columns and by the same uppercase letter in the rows do not differ by the Schott-Knott Test at the $5 \%$ probability level. CN (negative control) and CP (positive control), fungicidal control (Opera). 
Table 3. In vivo antifungal activity of the essential oils from four Eucalyptus species against $H$. vastatrix.

\begin{tabular}{lccccccc}
\hline & E. cit & E. gra & E. mic & E. cam & NC & M & FC \\
\hline Curative effect & 3 & 3 & 2 & 2 & 4 & 4 & 1 \\
Preventive effect & 2 & 1 & 4 & 2 & 4 & 4 & 1 \\
\hline 1-Leaves without sporulated pustules; 2-Leaves with slightly sporulated pustules; 3-More than 50\% of sporulated pustules; 4-Totally sporulated pustules. NC: negative
\end{tabular}

control; M: milk; FC: fungicide control; E cit: E. citriodora; E gra: E. grandis; E mic: E. microcorys; E cam: E. camaldulensis

Pereira et al. (2012a) studied the antifungal activity of the essential oil from E. citriodora and observed cellular disorganization and vacuolization in urediniospores of $H$. vastatrix. It is assumed that the same thing might have occurred with the essential oils used in this work, especially that from E. grandis. It was found that the spores had a colorless appearance after treatment with this essential oil.

\section{Determination of the in vivo antifungal activity}

The results of the in vivo antifungal activity of the essential oils from the Eucalyptus species are presented in Table 3. Antifungal activity was observed in vivo for most of the essential oils, except the essential oil from E. microcorys, for which no preventive antifungal activity against the proliferation of the $H$. vastatrix fungus was seen.

The coffee leaves sprayed with the powdered milk solution and water received the score 4 because all the postules were sporulated. The powdered milk and the water had no effect on the $H$. vastatrix fungus. Thus, the presence of these components had no effect on the inhibition of sporulation observed with the formulations containing the essential oils. The equal values for the curative effect obtained for the essential oils from E. Camaldulensis and E. microcorys might be related to the presence of the principal compounds $\alpha$ pinene, 1,8-cineol, and $\alpha$-terpineol in these essential oils. Equal antifungal activities for the curative effect were also observed for the other two essential oils from $E$. grandis and E. citriodora. The inoculum of $H$. vastatrix was reduced from $100 \%$ to slightly more than $50 \%$ sporulated pustules in the leaves of the coffee tree using both oils. However, their chemical compositions are not similar. The constituents present in these essential oils are not the same although they both exerted antifungal activity against the microorganism under study.

Antifungal activity was observed for the essential oil from $E$. mycrocorys when the curative effect was evaluated. A residual percentage of spores of less than $50 \%$ was obtained. However, no preventive activity was seen for this essential oil, while a $100 \%$ sporulation of the leaves contaminated with coffee rust was occurred. The constituents present in this essential oil probably act directly against the sporulation of $H$. vastatrix, leading to the death of the microorganism, but they do not act as inducers of defenses in plants. When the preventive effect of the essential oil from $E$. grandis was evaluated, this oil stood out from the others, by which $100 \%$ of the sporulation was inhibited. That is why the penetration of the fungus into the plant was prevented.

The resistance induced by the essential oils has already been mentioned by Pereira et al. (2012b). These authors verified the fact that the treatment of coffee seedlings with the essential oil from citronella inhibited the sporulation of $H$. vastatrix by $46 \%$ as a result of the increase in the coffee's defense enzymes. The same action might have occurred after the treatment of coffee seedlings with the essential oils from E. citriodora, E. grandis and E. camaldulensis, although these oils have different chemical compositions.

Bonaldo et al. (2007) investigated the aqueous extract of $E$. Citriodora, and observed a $10 \%$ increase in the production of phytoalexins in soybean cotyledons after the treatment, and concluded that the extract had the capacity to activate defense mechanisms in this plant. The same effect could have occurred after the treatment of the coffee seedlings with the essential oil from $E$. citriodora, wherein the preventive effect on $H$. vastatrix was evaluated, and the coffee seedlings were induced to create a defense mechanism against the microorganism. Because both the extract from $E$. citriodora and its essential oil contained a larger amount of citronellal than the other constituents, the antifungal activity of the essential oil and the aqueous extract of $E$. citriodora could be related to the principal constituent, citronellal.

The antifungal activity of essential oils can be attributed to their lipophilia. This feature allows them to interact with the fungal cell membrane composed of ergosterol and to inhibit the biological activities of this hormone. Another mechanism involves the disruption of this membrane by the essential oils and damage to several organelles, leading to the extravasation of ions and cellular materials, causing the death of the microorganism (Pinto et al., 2009).

The essential oils of the four species of Eucalyptus had different chemical compositions, and in vitro and in vivo antifungal activities was observed for all of the oils, except the essential oil of E. Mycrocorys, which did not exhibit in vivo antifungal activity as a curative agent. Thus, a better understanding of the mechanism of the antifungal activity of essential oils and a possible formulation can facilitate the application of these natural products in the field to inhibit the growth of microorganisms that impair the production of coffee beans.

\section{Materials and Methods}

This study was performed at the Laboratory of Organic Chemistry - Essential Oils and at the Agricultural Research Company of Minas Gerais located at the Federal University of Lavras during the period from February to December 2018. The university is located in the city of Lavras in the state of Minas Gerais at an altitude of $919 \mathrm{~m}$ and geographical coordinates: Latitude 21 14' 43" South and Longitude 44은 59' 59 "West.

\section{Obtaining plant material and extraction of essential oils}

The leaves of four Eucalyptus species were collected on hot days in the morning at the Forest Engineering Department of the Federal University of Lavras, MG (DEF/UFLA/MG/Brazil) and sent to the Laboratory of Organic Chemistry - Essential Oils (DQI-UFLA/MG/Brazil), where they were cleaned, chopped and weighed. The E. citriodora, E. camaldulensis, $E$. grandis and E. microcorys trees were used for collection of the plant material have registration numbers (10150), 
(10533/10266), (48) and (8717), respectively. Extractions of the essential oils were performed during a period of two hours in the Laboratory of Organic Chemistry - Essential Oils, DQI, UFLA by the hydrodistillation technique using a modified Clevenger apparatus (Brazil, 2010).

\section{Chemical characterization of essential oils}

The chemical characterization of the essential oils was accomplished at the UFLA Chemical Analysis and Prospecting Center (CAPQ) using a gas chromatograph coupled with a mass spectrometer detector (GC/MS) and a gas chromatograph with a flame ionization detector (GC/FID). The constituents of the essential oils were identified using a Shimadzu GC-17 A instrument with a model QP 5050A mass selective detector under the following experimental conditions: fuzed silica capillary column $(30 \mathrm{~m} \times 0.25 \mathrm{~mm})$ with a DBS bound phase $(0.25 \mu \mathrm{m}$ film thickness). The carrier gas was helium at a flow rate of $1.18 \mathrm{~mL} \mathrm{~min}^{-1}$ at $210^{\circ} \mathrm{C}$. The temperature program initiated at $60{ }^{\circ} \mathrm{C}$, followed by an increase to $240{ }^{\circ} \mathrm{C}$ at $3{ }^{\circ} \mathrm{C} \mathrm{min}$. Subsequently, the column temperature increased at $10^{\circ} \mathrm{C} \mathrm{min}^{-1}$ until it reached $300{ }^{\circ} \mathrm{C}$, where it was held constant for $7 \mathrm{~min}$. The injector temperature was $220{ }^{\circ} \mathrm{C}$ and that of the detector (or interface) was $240^{\circ} \mathrm{C}$. A $0.1-\mu \mathrm{L}$ aliquot of the sample diluted at a ratio of 1:100 in hexane was injected; a mixture of hydrocarbons $\left(\mathrm{C}_{9} \mathrm{H}_{20}, \mathrm{C}_{10} \mathrm{H}_{22}, \ldots, \mathrm{C}_{24} \mathrm{H}_{50}, \mathrm{C}_{25} \mathrm{H}_{52}, \mathrm{C}_{26} \mathrm{H}_{54}\right)$ was also injected. The impact energy was $70 \mathrm{eV}$.

Quantification of the constituents was performed using a gas chromatograph (Shimadzu CG-17A) with a flame ionization detector (FID). The experimental parameters for the analyses were the same as those used in the identification of the chemical constituents by GC/MS. The detector temperature was $300^{\circ} \mathrm{C}$.

The constituents were identified by comparing the retention indices relative to the homologous series of alkanes (nC8$\mathrm{nC18}$ ), calculated according to the method of Van Den Dool and Kratz (1963) with extrapolation for C19 and C20, using the retention indexes from the literature according to Adams (2009). The data were also compared with two NIST107 and NIST2 libraries available in the instrument. It was also possible to compare the spectra of the samples with those already existing in the literature (Nist. 2010).

\section{Determination of in vitro antifungal activity of the essential oils against $H$. vastatrix}

The antifungal activity was determined using the microdilution test, in which the percentage of germination was evaluated according to the method used by Silva et al. (2014), with modifications. Inoculations collected in the field were diluted in water to a concentration of $10^{6}$ spores per $\mathrm{mL}^{-1}$, counted in a Neubauer chamber. Aliquots of 300 $\mu \mathrm{L}$ of the inoculum were transferred to 6-cm-diameter Petri dishes containing a mixture of $5 \mathrm{~mL}$ of $2 \%$ agar/water culture medium. Aliquots of $0.25 ; 0.50 ; 1.25 ; 2.5 ; 5.0 ; 7.5$; 10.0 ; and $15.0 \mu \mathrm{L}$ of the essential oils were added to these dishes to furnish the final concentrations of 50,100, 250, $500,1000,1500,2000$ and $3000 \mu \mathrm{L}^{-L^{-1}}$ for each treatment. The negative control was accomplished using $5 \mathrm{~mL}$ of $2 \%$ agar/water culture medium and $300 \mu \mathrm{L}$ of inoculum. The positive control contained $15.0 \mu \mathrm{L}$ of the Opera ${ }^{\circledR}$ control fungicide, which is the dose proportional to that recommended by the manufacturer. Plates were incubated in BOD at $25{ }^{\circ} \mathrm{C}$ for a period of 24 hours. To count the spores, the upper right portion of the Petri dish was standardized to perform the readings under a microscope.

\section{Determination of in vivo antifungal activity of essential oils against $H$. vastatrix}

The in vivo tests of the essential oils against the $H$. vastatrix fungus were based on studies performed by Pereira et al. (2012b). Coffee seedlings of the Mundo Novo variety were used, and they were kept in a greenhouse at a controlled temperature of $30^{\circ} \mathrm{C}$ and a relative humidity of $47 \%$. The in vivo antifungal activity of the essential oils against the fungus was determined by evaluating the curative and preventive effects. These effects were determined by spraying the essential oils from E. microcorys, E. citriodora, $E$. camaldulensis and $E$. grandis, at the concentrations of $250,250,500$ and $1500 \mu \mathrm{L} . \mathrm{L}^{-1}$, respectively, on the abaxial part of the leaves.

For the evaluation of the curative effect, the seedlings were previously contaminated with $H$. vastatrix. In the evaluation of the preventive effect, the leaves of the coffee seedlings were inoculated with $H$. vastatrix two days arter the application of the essential oils. The concentrations of the essential oils used were determined on the basis of the IC measured in the in vitro tests. The negative control was performed using water, and the Opera ${ }^{\circledR}$ fungicide was applied in the positive control. A treatment with $10 \mathrm{~g} . \mathrm{L}^{-1}$ of a solution of milk powder was tested to evaluate whether it exerts antifungal activity because this solution was used as an emulsifying agent.

Twenty days after application of the essential oils to the coffee seedlings, the lesions were evaluated by comparing five leaves randomly collected from each treated seedling with five leaves randomly collected from the negative control. Evaluations of curative and preventive effects were performed using a scale from 1 to 4 , where 1 corresponded to leaves without spores; 2 , to leaves with few spore pustules; 3 , to leaves with more than $50 \%$ of sporulated pustules and 4 , to leaves with $100 \%$ sporulated pustules (Tamayo 1988).

\section{Statistical analysis}

To compare the results obtained in the in vitro tests, a completely randomized experimental design (DIC) with three replications was performed. The statistical program used was SISVAR (FERREIRA, 2011). Data were subjected to analysis of variance, and the means were compared by the Scott-Knott test at $5 \%$ probability for each essential oil, considering nine concentrations $(25,50,100,250,500$, $1000,1500,2000$ and $3000 \mu \mathrm{LL}^{-1}$ ). To understand the similarity of chemical constituents among essential oils, a principal component analysis (PCA) was performed using the Chemoface program (Nunes 2012).

\section{Conclusion}

The principal constituents of the essential oil from $E$. citriodora were citronellal, citronellol and iso isopulegol. $E$. camaldulensis had 1,8-cineole, $\alpha$-terpineol and $\alpha$-pinene. $E$. grandis principal constituents were 1,8-cineole, $\alpha$-pinene and $\alpha$-terpineol. The E. Microcorys were 1,8-cineole, $\alpha$ pinene and trans-pinocarveol. The essential oils extracted from E. grandis, E. citriodora, E. microcorys and $E$. camaldulensis inhibited $100 \%$ of the germination of $\mathrm{H}$. vastatrix spores at concentrations of $1000,50,50$ and 50 
$\mu \mathrm{L} . \mathrm{L}^{-1}$, respectively. In vivo antifungal activities were observed for all the essential oils, except for the essential oil from $E$. Microcorys, for which no in vivo antifungal activity was observed, but it acted as a preventive agent against $H$. vastatrix.

\section{Acknowledgments}

The authors acknowlede the financial support of the 001 Coordenação do Aperfeiçoamento de Pessoal de Nível Superior (CAPES), the Conselho Nacional de Desenvolvimento Científico e Tecnológico (CNPQ) and the Fundação de Amparo à Pesquisa do Estado de Minas Gerais (FAPEMIG). We also thank the Empresa de Pesquisa Agropecuária de Minas Gerais (EPAMIG) for furnishing a laboratory for performing the experiments.

\section{References}

Adams R P (2009) Identification of essential oils components by gas chromatography / mass spectroscopy, fourth ed. Allured, Carol Stream.

Barbosa LCA, Filomeno CA, Teixeira RR (2016) Chemical variability and biological activities of Eucalypttus spp. essential oils. Molecules. 21, 1671-1703.

Bonaldo SM, Schwan-Estrada KRF, Stangarlin J R, Cruz MES, Fiori-Tutida ACG et al. (2007) Ontribuição ao estudo das atividades antifúngica e elicitora de fitoalexinas em sorgo e soja por eucalipto (Eucalypttus citriodora). Summa Phytopathol. 33, 383-387.

Brasil. Agência Nacional de Vigilância Sanitária (ANVISA). (2010). Farmacopeia Brasileira, fifth ed., 198-199. Fiocruz, Brasília.

Brasil (2017) - Ministério da Agricultura Pecuária e Abastecimento (Mapa). http://www.agricultura.gov.br/assuntos/politicaagricola/cafe/cafeicultura-brasileira (acessed in 07 April 2018).

Dogan G, Kara N, Bagci E, Gur S (2017) Chemical composition and biological activities of leaf and fruit essential oils from Eucalypttus camaldulensis. Z Naturforsch. 72, 483-489.

Fathi E, Sefidkon F (2012) Influence of drying and extraction methods on yield and chemical composition of the essential oil of Eucalyptus sargentii. J Agr Sci Tech. 14: 1035-1042

Ferreira D (2011) Ssvar: a computer statistical analysis system. Ciênc Agrotec. 35(6):1039-1042.

Estanislau AA, Barros FAZ, Peña AP, Santos SC, Ferri PH, Paula JR (2001) Composição química e atividade antibacteriana dos óleos essenciais de cinco espécies de Eucalypttus cultivadas em Goiás. Rev Bras Farmacogn. 11, 95-100.

Gobbo-Neto and Lopes L (2007) Plantas medicinais: fatores de influência no conteúdo de metabólitos secundários. Quím Nova. 30:374-381.
Heil M, Baldwin IT (2002) Fitness costs of induced resistance: emerging experimental support for a slippery concept. Trends in Plant Science. 7(1):61-67.

Kedia A, Prakash B, Mishra PK, Dwivedy AK, Dubey NK (2015) Trachyspermum ammi L. essential oil as plant based preservative in food system. Ind Crops and Prod. 69:104-9. NIST/ EPA/ NIH mass spectral library and search/ analysis programs. Hoboken, NJ: J. Wiley and Sons, (2010).

Nunes CA, Freitas MP, Pinheiro ACM, Bastos SC (2012) Chemoface: A novel free user-friendly interface for chemometrics. J Braz Chem Soc. 23:2003-2010.

Pereira RB, Lucas GC, Perina FJ, Alves E (2012a) Essential oils for rust control on coffee plants. Ciênc Agrotec. 36, 16-24.

Pereira RB, Lucas GC, Perina FJ, Junior PMR, Alves E (2012b) Citronella essential oil in the control and activation of coffee plants defense response against rust and brown eye spot. Ciênc Agrotec. 36:383-390.

Pinto E, Vale-Silva L, Cavaleiro C, Salgueiro L (2009) Antifungal activity of the clove essential oil from Syzygium aromaticum on Candida, Aspergillus and dermatophyte species. J Med Microbiol. 58: 1454-1462.

Rasooli I, Rezaei MB, Allameh A (2006) Growth inhibition and morphological alterations of Aspergillus niger by essential oils from Thymus eriocalyx and Thymus $x$-porlock. Food Control. 17: 359-364.

Rezende DACS, Souza RV, Magalhães ML, Caetano ARS, Carvalho MSS, Souza EC, Guimarães LGL, Nelson DL, Batista LR, Cardoso MG (2017) Characterization of the Biological Potential of the Essential Oils from Five Species of Medicinal Plants. Am J Plant Sci. 8:154-170.

Salgado APSP, Cardoso MG, Souza PE, Souza JA, Abreu CMP, Pinto JEBP (2003) Ungitoxic activity evaluation of essential leaf oils of Eucalyptus on Fusarium oxysporum, Botrytis cinerea and Bipolaris sorokiniana. Ciênc Agrotec. 27:249254

Silva JL, Souza PE, Monteiro FP, Freitas MLO, Silva JMB, Belan LL (2014) Antifungal activity using medicinal plant extracts against pathogens of coffee tree. Rev Bras Plant Med. 16(3): 539-544.

Silva PHM, Brito JO, Silva JFG (2006) Potential of eleven Eucalyptus species for the production of essential oils. Scientia Agricola. 63(1):85-89.

Steffen RB, Antoniolli ZI, Steffen GPK (2010) Efeito estimulante do óleo essencial de eucalipto na germinação e crescimento inicial de mudas de Eucalyptus grandis. Pesquisa Florestal Brasileira. 30(63):199.

Tamayo PJ (1988) Resistência de Progênies de Catimor a Oito Raças de Hemileia vastatrix Berk. et Br. 64p. Tese (Mestrado em Fitopatologia) - Universidade Federal de Viçosa, Viçosa.

Van Den Dool H, Kratz PD (1963) A generalization of the retention index system including linear temperature programmed gas-liquid partition chromatography. J Chromatogr. A. 11, 463-471.

Zambolim L (2016) Current status and management of coffee leaf rust in Brazil. Trop Plant Path. 41(1):1-8. 